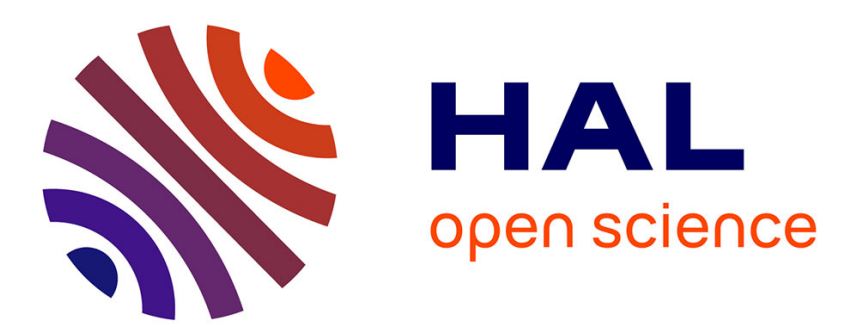

\title{
Electrochemical Energy Conversion from Direct Oxidation of Glucose on Active Electrode Materials
}

Charly Lemoine, Lionel Dubois, Teko Napporn, Karine Servat, Kouakou B Kokoh

\section{- To cite this version:}

Charly Lemoine, Lionel Dubois, Teko Napporn, Karine Servat, Kouakou B Kokoh. Electrochemical Energy Conversion from Direct Oxidation of Glucose on Active Electrode Materials. Electrocatalysis, 2020, 11 (2), pp.170-179. 10.1007/s12678-019-00570-1 . hal-03055025

\section{HAL Id: hal-03055025 https://hal.science/hal-03055025}

Submitted on 11 Dec 2020

HAL is a multi-disciplinary open access archive for the deposit and dissemination of scientific research documents, whether they are published or not. The documents may come from teaching and research institutions in France or abroad, or from public or private research centers.
L'archive ouverte pluridisciplinaire HAL, est destinée au dépôt et à la diffusion de documents scientifiques de niveau recherche, publiés ou non, émanant des établissements d'enseignement et de recherche français ou étrangers, des laboratoires publics ou privés. 
Electrochemical energy conversion from direct oxidation of glucose on active electrode materials

Charly Lemoine $^{\mathrm{a}} \cdot$ Lionel Dubois $^{\mathrm{b}} \bullet$ Teko W. Napporn $^{\mathrm{a}} \bullet$ Karine Servat $^{\mathrm{a}} \bullet$ Kouakou B. $^{\circ}$ Kokoh $^{\mathrm{a}, *}$

${ }^{\text {a }}$ Université de Poitiers, IC2MP UMR-CNRS 7285, Équipe SAMCat, 4 rue Michel Brunet B27, TSA 51106, 86073 Poitiers cedex, France

${ }^{\mathrm{b}}$ Univ. Grenoble Alpes, CEA, CNRS, IRIG, SyMMES, F-38000 Grenoble

${ }^{*}$ Corresponding author. Tel.: +33 549454120 Fax: +33 549453580 .

E-mail address: boniface.kokoh@univ-poitiers.fr (K.B. Kokoh).

ORCID: 0000-0002-5379-7792 
Abstract. Electrochemical behavior of carbon supported platinum and gold-based catalysts towards glucose oxidation and oxygen reduction reaction were investigated separately in alkaline medium before implementing the glucose $/ \mathrm{O}_{2}$ fuel cell with the best anode and cathode catalysts. These electrode materials, prepared from a surfactant-free synthesis approach, were then used in low metal loadings in a fuel cell operating in alkaline medium which can be easily removed on resin for analyzing all the reaction products, as any toxic compound has to be avoided for the interest of this specific application. Pt/rGO is the most active anode towards the glucose oxidation. For all tested catalysts, this oxidation reaction leads mainly to gluconate without chromatographically detectable reaction products resulted from $\mathrm{C}-\mathrm{C}$ bond cleavage.

Keywords: Glucose fuel cell $\bullet$ Carbon substrate Pt and Au electrodes $•$ Alkaline medium 


\section{Introduction}

The interest on glucose in the domain of energy production is increasing because this sugar, which is abundant in living being body, is a promising fuel for new implantable energy sources [1-4]. Enzymes, such as glucose oxidase, have been largely studied for enzymatic oxidation of glucose, showing good activity and selectivity, but their lack of stability has been reported as their principal weakness [5]. As a result, the lifetime of enzymatic fuel cells does not exceed several weeks, limiting their application to short-term implantable sensors. Thereby, research investigations have been focusing last decades on abiotic systems [6, 7]. The use of such catalysts made of supported metal nanoparticles as glucose fuel cell anode presents great advantages such as long-time stability, resistance to temperature modification, and large $\mathrm{pH}$ window.

In aqueous solution glucose takes a hemiacetalic form, which confers it two anomeric positions, $\alpha$ and $\beta$-glucose, the latter one being the more reactive at the electrode surface $[8,9]$. It is also reported that glucose dehydrogenation to glucono- $\delta$-lactone occurs better at low potentials at the platinum surface $[10,11]$, which is very sensitive to poisoning in the presence of the degradation products, for instance $\mathrm{CO}$ species [8]. For these reasons and considering the affinity of the $\mathrm{Au}$ anode towards aldehydes/hemiacetals, the association of $\mathrm{Au}$ and $\mathrm{Pt}$ as bimetallic electrode may lead to reduce the poisoning effect and emphasize the stability of the catalyst for long-term applications [12-15].

As the electrocatalytic activity of metal nanoparticles results from surface states, the performance of the catalyst is directly dependent of its available electrochemical surface area (ECSA), so on the size and morphology of the nanoparticles. The surface cleanliness is also very important because the electrocatalytic activity can be drastically inhibited by the adsorption of organic species such as capping agent during the synthesis. Furthermore, the supporting electrode plays a key role in the enhancement of the catalyst activity and stability. 
Supported materials not only maximize the availability of nanoparticles surface for electron transfer, but also provide better mass transport of reactants to the electrocatalyst. In addition, the conductive support facilitates efficient collection and transfer of electrons to the electrode surface [16]. Carbon black has been extensively employed because of its high electrical conductivity, surface area and low cost. Despite all that progress, the major obstacle for sustainable performances is the aggregation process of nanoparticles in time [17, 18]. A. Zadick et al. [19] observed a severe degradation of Pt deposited onto a Vulcan XC 72 substrate. Indeed, after 150 cycles in the potential range $0.1-1.23 \mathrm{~V}$ vs RHE in $0.1 \mathrm{M} \mathrm{NaOH}$ and at $25^{\circ} \mathrm{C}$, they noted $60 \%$ ECSA loss due to the Pt particles agglomeration. Recently, graphene derivatives like graphene oxide (GO) and reduced graphene oxide (rGO) have been reported to be promising electrode supports for metal nanoparticles growth in electrocatalysis field [20-25]. Graphene is composed of a single sheet of $\mathrm{sp}^{2}$ hybridized carbon with a huge surface area (theoretical value is $2630 \mathrm{~m}^{2} / \mathrm{g}$ ) and shows high career mobility, high electrical conductivity and an improved resistance to corrosion. Indeed, the $\mathrm{sp}^{2}$ hybridized carbon leads to an increased strength of $\pi$ sites on the support that acts as anchoring centers for platinum nanoparticles, thus strengthening the nanoparticle-support interaction [26]. Through its properties, rGO is a hopeful supporting material for ensuring to nanoparticles improvement of their electroactivity and longterm stability [27]. Accordingly, Au and Pt nanocatalysts were prepared by Bromide Anion Exchange (BAE) method [28]. This surfactant-free synthesis is based on the anion exchange of potassium bromide with the metal precursor salts before reduction by sodium borohydride, and allowed to obtain well-dispersed and small-sized nanoparticles without organic pollutant. Monometallic and bimetallic catalysts were synthetized on two different carbon supports: amorphous carbon Vulcan and reduced graphene oxide (rGO). The present investigation was done in alkaline medium, instead of physiological buffer, to remove the electrolyte easier than phosphate, which facilitates the identification of all reaction products and ensures the absence 
of any toxic intermediate or final products. Electrochemical behavior of the catalysts towards glucose oxidation and oxygen reduction reaction were investigated separately in alkaline medium before implementing the glucose $/ \mathrm{O}_{2}$ fuel cell with the best anode and cathode catalysts.

\section{Experimental}

Before using, all the glassware was successively cleaned in a mixed sulfuric acid and potassium permanganate solution then in acidic hydrogen peroxide solution and finally rinsed with boiling ultrapure water $\left(18.2 \mathrm{M} \Omega \mathrm{cm}\right.$ at $\left.20{ }^{\circ} \mathrm{C}\right) . \mathrm{KOH}(90 \%$, Sigma-Aldrich) solution was prepared with ultrapure water. $\mathrm{HAuCl}_{4}, 3 \mathrm{H}_{2} \mathrm{O}(99.9 \%), \mathrm{H}_{2} \mathrm{PtCl}_{6}, 6 \mathrm{H}_{2} \mathrm{O}(99.9 \%), \mathrm{NaBH}_{4}(99 \%)$ and D-(+)-glucose (99.5\%) were purchased from Sigma-Aldrich. $\mathrm{KBr}(99 \%)$ was purchased from Fisher Scientific. Filters Durapore Membrane, hydrophilic PVDF, $0.22 \mu \mathrm{m}, 47 \mathrm{~mm}$ were purchased from Merck. Amorphous carbon Vulcan XC-72R, purchased from Cabot was thermally treated at $400{ }^{\circ} \mathrm{C}$ under nitrogen atmosphere during $4 \mathrm{~h}$, as described elsewhere [29]. The rGO substrate was prepared by dissolving $16 \mathrm{~g}$ of commercial graphene in sulfuric acid $(400 \mathrm{~mL})$. Graphene nanoplatelets aggregates (sub-micron particles, surface area $750 \mathrm{~m}^{2} \mathrm{~g}^{-1}$ from STREM chemical), and sulfuric acid were purchased from Sigma-Aldrich. The mixture was stirred for 7 hours at $200{ }^{\circ} \mathrm{C}$. After cooling, an acidic solution was carefully added in $400 \mathrm{~mL}$ of water and the obtained suspension was transferred to two beakers for its decantation. After removal of the acidic phase, the washing process (400 $\mathrm{mL}$ of water) was repeated three times. The obtained black paste was separated by filtration and washed with water until pH 5-6. The extra-exfoliated graphene was lyophilized and then dried in a vacuum oven for $24 \mathrm{~h}$ at $80{ }^{\circ} \mathrm{C}$. Then, $5 \mathrm{~g}$ was put in a vitreous carbon boat located in a silica tube with a $\mathrm{H}_{2} 10 \% / \mathrm{Ar}$ inlet $\left(3 \mathrm{~L} \mathrm{~h}^{-1}\right)$. The system was placed in a tubular oven and thermally treated during $4 \mathrm{~h}$ at $750{ }^{\circ} \mathrm{C}$ with a $5^{\circ} \mathrm{C} \min ^{-1}$ rate. After cooling, $3.5 \mathrm{~g}$ of over reduced rGO was finally obtained. 


\section{Preparation of the electrode materials from the BAE synthetic method}

$\mathrm{Au}$ and/or Pt salts were introduced in a $500 \mathrm{~mL}$ round bottom flask and dissolved in MilliQ water to have $1 \mathrm{mM}$ metallic cation in a $100 \mathrm{~mL}$ solution. After stirring for $10 \mathrm{~min}$ at room temperature to homogenize the solution, $\mathrm{KBr}$ was introduced to have a ratio of $\mathrm{n}(\mathrm{KBr}) / \mathrm{n}($ metal $)$ equal to $1.46,[30]$ stirring for $10 \mathrm{~min}$ to allow the ionic exchange between the bromide and the chloride. Afterwards, a quantity of carbon was added, corresponding to a final hybrid material $\mathrm{M} / \mathrm{C}$ of $20 / 80$ wt. $\%$. This solution was then ultrasonicated for 45 min without temperature control. $15 \mathrm{~mL}$ of $0.1 \mathrm{M} \mathrm{NaBH}_{4}$ was prepared and cooled down with ice during $10 \mathrm{~min}$. The reducing solution was introduced dropwise into the flask under vigorous stirring at room temperature. Finally, the resulting solution was maintained under stirring in an oil bath at $40{ }^{\circ} \mathrm{C}$ during $2 \mathrm{~h}$ then filtered. The solid was dried in an oven at $70^{\circ} \mathrm{C}$ overnight.

\section{Physicochemical characterizations}

X-Ray Diffractometry (XRD). XRD patterns were obtained with an Empyrean (PANanalytical) diffractometer in Bragg-Brentano $(\theta-\theta)$ configuration. X-rays are generated by a copper anode powered at $45 \mathrm{kV}$ and $40 \mathrm{~mA} . \mathrm{Cu} \mathrm{K} \alpha_{1}(\lambda=0.15406 \mathrm{~nm})$ primary beam was isolated thanks to a nickel filter installed in secondary optical before the linear detector XCelerator, which open window has been set on $5^{\circ}$. Patterns were recorded between scattering angles $2 \theta=15^{\circ}$ and $130^{\circ}$, with a step of $0.05^{\circ} / 2 \theta$ and an acquisition time of 2 min by step.

Transmission Electron Microscopy (TEM). Nanocatalysts were examined with a JEOL 2100 UHR TEM equipped with a $\mathrm{LaB}_{6}$ filament. Images were obtained in bright field using a $200 \mathrm{kV}$ accelerating voltage and a maximum resolution of $0.19 \mathrm{~nm}$.

Raman spectroscopy. The analyses were performed with a HORIBA JOBIN YVON Labram HR800UV confocal microscope equipped with a CCD detector 74 cooled by the Peltier effect. The primary radiation (power of $0.05 \mathrm{~mW}$ ) was produced by an $\mathrm{Ar}+$ laser (Melles Griot) with 
a wavelength of $514.5 \mathrm{~nm}$. An optical density filter was used to limit the irradiation of the sample. A $600 . \mathrm{mm}^{-1}$ diffraction grating was used and the confocal hole opening was fixed at $400 \mu \mathrm{m}$. The spectral resolution was $1.5 \mathrm{~cm}^{-1}$ and the survey area was about $1 \mu \mathrm{m}^{2}$. The spectrometer was previously calibrated with a silicon sample. A Pseudo-Voigt function was used to decompose the spectra.

X-Ray Photoelectron Spectroscopy (XPS). The XPS analyses were performed with a Kratos Axis Ultra DLD spectrometer equipped with a monochromatic Al Mono radiation source $(\mathrm{K} \alpha(\mathrm{Al}): 1486.6 \mathrm{eV})$ operating at $150 \mathrm{~W}(15 \mathrm{kV}$ and $10 \mathrm{~mA})$. The supported catalysts were placed on a copper support and introduced into the high vacuum chamber (10-12 bar) through an airlock. The irradiated surface was $0.3 \times 0.7 \mathrm{~mm}^{2}$. The high-resolution spectra were performed with a step of $0.1 \mathrm{eV}$. The background noise was subtracted and the KE values were systematically corrected with respect to the $\mathrm{C} 1 \mathrm{~s}$ band energy which must be at $284.2 \mathrm{eV}$ with this device. The energy bands were deconvoluted and modelled by combining a Gaussian function and a Lorentzian function, modulated by an asymmetry factor.

Analysis of the reaction products by ionic chromatography. Samples were characterized in a Dionex ISC 5000 apparatus, equipped with a conductimetric detector, very sensitive and specific to carboxylic compounds (CD-5000) followed by an amperometric one (ED-5000), which is selective to carbohydrate analysis. Before the chromatographic characterization, the samples were passed through a cationic resin (DOWEX 50WX8-200 from Sigma-Aldrich) to remove the electrolyte $\left(\mathrm{K}^{+}, \mathrm{HO}^{-}\right)$and to convert carboxylate to their protonic form. Then the solution was frozen and lyophilized (Freeze PowerDry LL3000, Thermo scientific) to remove water. The resulting solid was diluted in $4 \mathrm{~mL}$ of water, and $20 \mu \mathrm{L}$ of solution is injected by an AS50 autosampler into the eluent and flows through an IonPac AS15, 2 × $250 \mathrm{~mm}$ column. The eluent was $10 \mathrm{mM} \mathrm{NaOH}$ and a constant $0.3 \mathrm{~mL} \mathrm{~min}^{-1}$ flow rate was employed. 


\section{Catalytic inks formulation}

Catalytic inks were prepared as follows:

A. Ink composition for voltammetry: $4 \mathrm{mg}$ of M/C catalyst, $500 \mu \mathrm{L}$ water, $100 \mu \mathrm{L}$ isopropanol, $50 \mu \mathrm{L}$ of $\mathrm{Nafion}^{\circledR}$ emulsion solution 5 wt. $\%\left(1.23 \mathrm{mg}_{\text {metal }} \mathrm{mL}^{-1}\right)$.

B. Ink composition for fuel cell tests: $4 \mathrm{mg} \mathrm{M} / \mathrm{C}$ catalyst, $300 \mu \mathrm{L}$ water, $25 \mu \mathrm{L}$ of Nafion ${ }^{\circledR}$ emulsion solution 5 wt. \% $\left(2.46 \mathrm{mg}_{\text {metal }} \mathrm{mL}^{-1}\right) .23 \mu \mathrm{L}$ of ink is deposited onto each face of a carbon paper sheet $\left(2 \times 0.5 \mathrm{~cm}^{2}\right)$ to have a covered surface of $0.3 \mathrm{~cm}^{2}$ on each face, corresponding to a mass loading of $0.19 \mathrm{mg}_{\text {metal }} \mathrm{cm}^{-2}$.

\section{Electrochemical characterizations.}

Cyclic voltammetry $(\mathrm{CV})$. $\mathrm{CV}$ measurements were performed at room temperature using an Autolab PGSTAT $302 \mathrm{~N}$ potentiostat connected to a three electrodes glass cell. A glassy carbon slab and $\mathrm{Hg} / \mathrm{HgO}$ electrode (MOR) purchased from ALS Co, were used as counter and reference electrodes, respectively. The last one was introduced in a glass extension with a platinum wire at the tip to ensure the electrical conduction with the solution in the cell. $3 \mu \mathrm{L}$ of ink A was deposited onto $3 \mathrm{~mm}$ diameter glassy carbon disk inserted in a Teflon cylinder and dried under nitrogen flux while rotating at $600 \mathrm{rpm}$. Finally, the catalyst metal loading which composed the working electrode was estimated at $52 \mu \mathrm{g}_{\text {metal }} \mathrm{cm}^{-2}$. The electroactivity of the prepared materials was measured in $\mathrm{N}_{2}$-saturated supporting electrolyte $0.1 \mathrm{M} \mathrm{KOH}$ between 0.88 and $0.27 \mathrm{~V}$ vs. MOR, corresponding to 0.05 and $1.20 \mathrm{~V}$ vs RHE. Potential cycling was done at $50 \mathrm{mV} \mathrm{s}^{-1}$ scan rate to stabilize the catalyst surface before recording two other ones at $20 \mathrm{mV} \mathrm{s}^{-1}$, in the absence and the presence of $50 \mathrm{mM}$ glucose.

Direct Glucose Fuel Cell testings (DGFC). The DGFC consists of two compartments, anodic and cathodic, separated by a Fumatech anion membrane. Each compartment was filled with 20 $\mathrm{mL}$ of the support electrolyte $(0.1 \mathrm{M} \mathrm{KOH})$, and glucose was added in the anodic one to reach 
$50 \mathrm{mM}$. The anodic compartment was deaerated with an inert gas (nitrogen), while bubbling oxygen in the cathodic side for the ORR process. Electrodes were made of $2 \times 0.5 \mathrm{~cm}^{2}$ carbon Toray sheets, electrically connected with a Pt wire and covered on both sides with ink B to obtain $2 \times 0.3 \mathrm{~cm}^{2}$ of covered surface. Steady-state currents were applied to the two electrodes, and the resulting cell voltage was recorded with an Autolab PGSTAT 302N potentiostat, while tiny $\mathrm{Ag} / \mathrm{AgCl}$ reference electrodes were added in each compartment to measure the electrode potentials at the anode and the cathode, separately, during the fuel cell operation.

\section{Results and discussion}

rGO supported nanocatalysts were characterized by X-ray diffractometry (XRD). Part of the recorded diffractograms is displayed in Figure 1. A zoom in the range $2 \theta=37^{\circ}$ to $41^{\circ}$ allows to appreciate the coexistence of the metallic particles thanks to the $\mathrm{Au}$ (111) and $\mathrm{Pt}$ (111) planes: the maximum of the $\mathrm{Au}(111)$ diffraction peak shifts from $38.209^{\circ}(\mathrm{Au} / \mathrm{rGO})$ to $38.271^{\circ}$ $\left(\mathrm{Au}_{30} \mathrm{Pt} \mathrm{t}_{0} / \mathrm{rGO}\right)$. Also, the $\mathrm{Pt}(111)$ diffraction peaks shifts from $39.953^{\circ}(\mathrm{Pt} / \mathrm{rGO})$ to $39.878^{\circ}$ $\left(\mathrm{Au}_{50} \mathrm{Pt}_{50} / \mathrm{rGO}\right)$. Moreover, the more $\mathrm{Au}$ is present, the more intense is its (111) reflection plane and the less intense is the Pt (111) one. According to the Vegard's law, most of the metallic phases are not alloyed. The crystallite sizes extracted on the (111) planes from Debye-Scherrer equation and Bragg's law comprise between 5-10 and 10-15 nm for Pt and Au, respectively. TEM images of the same catalysts depicted in Figure 2 show a good dispersion and a small particles size; the mean particle size resulted from counting more than 300 particles was $1.8 \pm 0.2 \mathrm{~nm}$ for both Pt catalysts and $4.4 \pm 0.5 \mathrm{~nm}$ for $\mathrm{Au} / \mathrm{rGO}$. That observations suggest a large available electroactive surface, suitable to optimize the electrocatalytic activity towards glucose oxidation.

The structural properties of the carbon supports were investigated using Raman spectroscopy. The spectra recorded in the 800 to $2000 \mathrm{~cm}^{-1}$ range are displayed in Figure 3a for Vulcan and 
Figure 3b for rGO. Their simulated profile and deconvolution were done using Pseudo-Voigt function. Both spectra show a band centered at $1200 \mathrm{~cm}^{-1}$, commonly associated with the presence of $\mathrm{sp}^{3}$ rich-domains (polyene-like structures). The D band centered at $1340 \mathrm{~cm}^{-1}$ is characteristic of the disorder in the materials [31-34], and is thinner in the case of rGO. The third band centered at $1515 \mathrm{~cm}^{-1}$ and visible for both materials traduces the presence of amorphous $\mathrm{sp}^{2}$ domains [35]. The $\mathrm{G}$ band, associated with the inter-plane vibration of $\mathrm{sp}^{2}$ carbon network [36], is shifted from $1596 \mathrm{~cm}^{-1}$ for Vulcan to $1578 \mathrm{~cm}^{-1}$ for rGO, for which the $\mathrm{G}$ band is also thinner. Moreover, an extra-band centered at $1615 \mathrm{~cm}^{-1}$ only appears in $\mathrm{rGO}$ spectra. It corresponds to the D' mode and is related to the presence of intercalated graphite compounds [37]. From that fitting some structural parameters have been extracted: the size of the graphitic domains $L_{a}$ and the graphitization degree corresponding to the ratio of $\mathrm{D}$ and $\mathrm{G}$ bands integrated intensity $\mathrm{I}_{\mathrm{D}} / \mathrm{I}_{\mathrm{G}}$. The $L_{\mathrm{a}}$ value in $\mathrm{nm}$ was calculated according to equation 1 [38]:

$L_{a}=2.410^{-10} \lambda_{\text {laser }} 4 \frac{I_{G}}{I_{D}}$

Table 1 compares the calculated values and show that the difference is very small. Despite all the common bands traducing presence of $\mathrm{sp}^{2}$ and $\mathrm{sp}^{3}$ domains in both materials, and that calculated values of $\mathrm{I}_{\mathrm{D}} / \mathrm{I}_{\mathrm{G}}$ and $L_{\mathrm{a}}$ are close, the width of $\mathrm{D}$ and $\mathrm{G}$ bands, the shift of the $\mathrm{G}$ band and the presence of the $\mathrm{D}^{\prime}$ band show a more ordered structure of rGO compared to Vulcan [39].

Electronic interactions occurring between metals were investigated by XPS measurements. As can be observed on Figures $\mathbf{4 a}$ and $\mathbf{4 b}$, the peaks corresponding to $\mathrm{Pt} 4 \mathrm{f}_{5 / 2}$ and $\mathrm{Pt} 4 \mathrm{f}_{7 / 2}$ orbitals are located, respectively, at $74.6 \mathrm{eV}$ and $71.3 \mathrm{eV}$ in monometallic catalysts $\mathrm{Pt} / \mathrm{Vulcan}$ and $\mathrm{Pt} / \mathrm{rGO} . \mathrm{PtO}_{2}$ and $\mathrm{PtO}_{\mathrm{x}}$ species are detected in both catalysts, at a proportion of $\mathrm{Pt}$ oxides calculated at respectively 19 wt. \% and 28 wt. \% for Pt/Vulcan and Pt/rGO. On the XPS spectra of the bimetallic catalysts (Figures $\mathbf{4 c}$ and $\mathbf{4 d}$ ), the position of Pt $4 \mathrm{f}$ peaks do not shift when 
compared to the monometallic ones; this explain the non-alloy nature of $\mathrm{Au}$ and $\mathrm{Pt}$ in the bimetallic $\mathrm{Au}_{70} \mathrm{Pt}_{30} / \mathrm{rGO}$ and $\mathrm{Au}_{50} \mathrm{Pt}_{50} / \mathrm{rGO}$ materials. [40]

CO-stripping investigations were performed on Pt-containing catalysts in $0.1 \mathrm{M} \mathrm{KOH}$ electrolyte. This experiment consists in adsorbing a monolayer of $\mathrm{CO}$ at the electrode surface by successive saturation of solution with $\mathrm{CO}$ gas, then with $\mathrm{N}_{2}$ in order to remove from the electrolytic solution all free $\mathrm{CO}$, i.e. except the monolayer under potential of $0.10 \mathrm{~V}$ vs RHE. Then a CV was recorded to oxidize CO during the first anodic scan, while the second cycle would exhibit a reference Pt, Au or AuPt electrode surface. Voltammograms of the prepared materials characterized by CO-stripping can be seen in Figure 5. The dispersion of Pt nanoparticles on the carbon substrate is more favorable to Vulcan than rGO when regarding the shift of the CO oxidation peak from 0.71 (rGO) to $0.68 \mathrm{~V}$ vs RHE (Vulcan). For the same bimetallic composition $\left(\mathrm{Au}_{70} \mathrm{Pt}_{30}\right)$, a similar trend is observed $(\Delta \mathrm{E}=28 \mathrm{mV})$ from $\mathrm{Au}_{70} \mathrm{Pt}_{30} / \mathrm{rGO}$ to $\mathrm{Au}_{70} \mathrm{Pt}_{30} /$ Vulcan. Whatever the carbon substrate, the presence of Au leads to a small shift of the CO-to- $\mathrm{CO}_{2}$ oxidation peak toward lower potential values $(-22 \mathrm{mV})$ on the $\mathrm{Au}_{70} \mathrm{Pt}_{30}$ bimetallic catalysts compared to Pt alone (Figure 5).

Calculations of specific electrochemical surface areas (SECSA) summarized in Table 2 were calculated according to equation 2 [41]:

$S E C S A=\frac{E C S A}{m_{P t}}=\left(\int_{E_{\text {onset }}}^{E_{\text {offset }}} \Delta I(E) d E\right) \times \frac{1}{v \times Q_{m l} \times m_{P t}}$

where $E_{\text {onset }}$ and $E_{\text {offset }}$ are the onset and offset potentials of $C O$ oxidation, $\Delta \mathrm{I}(\mathrm{E})$ the difference of intensity between the first and the second anodic scan, $v$ the scan rate $\left(20 \mathrm{mV} \mathrm{s}^{-1}\right), Q_{m l}$ the charge associated with the desorption of a $\mathrm{CO}$ monolayer $\left(420 \mu \mathrm{C} \mathrm{cm}^{-2}\right)$, and $m_{P t}$ the mass of platinum on the electrode. Calculations were normalized to the mass of Pt because $\mathrm{Au}$ is not active in CO-stripping [42]. The SECSA values obtained are higher when the nanoparticles are deposited onto the rGO substrate than the same compositions onto Vulcan (Table 2). Moreover, the addition of the Au content in the Pt based materials improves not only the onset potential 
of $\mathrm{CO}$ oxidation, but also the activity of the bimetallics that present higher SECSA than those found for monometallics. Although the monometallic materials deposited onto Vulcan and rGO are similar sizes, the better activity exhibited by those onto rGO may be due to the performance of the charge transfer between the catalysts and the rGO support.

The prepared materials were characterized in alkaline medium. First of all, their recording in a supporting electrolyte allows to reveal the presence of $\mathrm{Pt}$ in $\mathrm{Pt} / \mathrm{rGO}$ and in the bimetallic compositions (Figure 6a).

Although the $\mathrm{CV}$ of $\mathrm{Au} / \mathrm{rGO}$ does not reflect the standard shape, the $\mathrm{CV}$ in the presence of glucose (Figure 6b) shows the expected oxidation peaks in alkaline medium, as recently reported [43]. As the glucose oxidation occurs earlier at the Pt surface via dehydrogenation on the anomeric carbon position [8], one can observe that the $\mathrm{Au}_{70} \mathrm{Pt}_{30} / \mathrm{rGO}$ anode has a similar electrochemical behavior than $\mathrm{Pt} / \mathrm{rGO}$ in the Pt-like hydrogen zone between 0.05 and $0.40 \mathrm{~V}$ vs RHE. When comparing the current densities at low potential of an anode in a fuel cell application, with $30 \%$ less $\mathrm{Pt}$ than $\mathrm{Pt} / \mathrm{rGO}$, the $\mathrm{Au}_{70} \mathrm{Pt}_{30} / \mathrm{rGO}$ catalyst is as active as $\mathrm{Pt}$ alone. For the cathodic counterpart, oxygen reduction reaction (ORR) has been studied in alkaline media on Pt/Vulcan containing a wt. $20 \%$ metal loading. Linear sweep voltammograms, displayed in Figure 7, have been recorded at $5 \mathrm{mV} \mathrm{s}^{-1}$ scan rate in a $\mathrm{O}_{2}$-saturated $0.1 \mathrm{M} \mathrm{KOH}$ solution, using a rotating disk electrode at different rotation rates (from 400 to $2500 \mathrm{rpm}$ ). The onset potential of ORR and the half-wave potential at $1600 \mathrm{rpm}$ were found at 1.06 and $0.78 \mathrm{~V}$ vs RHE, respectively, showing a good activity of this catalyst towards the ORR. The number of electrons involved in the $\mathrm{O}_{2}$ reduction reaction was estimated at 3.7 using Levich equation at $0.30 \mathrm{~V}$ vs RHE, which suggests a 4-electron pathway in the cathodic side [44].

The first investigations of the glucose $/ \mathrm{O}_{2}$ fuel cell were undertaken with two series of experiments, one on Vulcan supported catalysts (Figure 8a), while the second operation was performed at the anodes deposited onto rGO (Figure 8b). The evolution of the cell voltage 
versus current density in the home-made fuel cell containing a Fumatech anion exchange membrane, reveals that i) the power density increases as function of Pt content in the anodic composition; ii) the open circuit voltage (OCV) also increases with the Pt content when the catalyst was dispersed on a Vulcan substrate; iii) for the rGO supported catalysts the OCV with the gold anode increases slightly, while the Pt-containing electrocatalysts permit to deliver the same OCV values of $0.94 \mathrm{~V}$. As result, the highest values of cell voltage and power density are obtained with Pt monometallic anodes, and the lowest, on the Au monometallic ones. Considering that the cathode potential remains stable for each experiment, the cell voltage is only dependent of the anode behavior. The glucose $/ \mathrm{O}_{2}$ fuel cell delivers a maximum power density of 900 and $1080 \mu \mathrm{W} \mathrm{cm}{ }^{-2}$ on the Pt/Vulcan and Pt/rGO anodes, respectively. The $\mathrm{Au}_{70} \mathrm{Pt}_{30}$ catalyst displays an intermediary activity compared to $\mathrm{Au}$ and Pt. Finally, all the rGO supported catalysts show higher electrochemical performances than those analogous deposited onto Vulcan. On can conclude that the structure of the carbon substrate clearly influences the activity of the catalysts.

Different bimetallic AuPt compositions of rGO supported catalysts were also tested in the glucose $/ \mathrm{O}_{2}$ fuel cell to find the best operating conditions and the most active anode (Figure 9). The same OCV of $0.94 \mathrm{~V}$ was obtained for $\mathrm{Pt} / \mathrm{rGO}$ and all bimetallic catalysts. Considering the relation observed in TEM (Figure 2) between agglomeration and Pt loading in bimetallic nanoparticles, that order of activity cannot be correlated to the particle size or the electrochemical active surface but directly to the Pt amount in the bimetallic composition. Indeed CO-stripping results show that the Pt amount at the surface is higher for rGO supported materials (Table 2).

The electrochemical performances recorded herein are in the same order than those recently reported, $[6,15,45-48]$ even if the concentrations of glucose and the supporting electrolyte are 5 and 10 times lower in our case. Due to their simple preparation method from BAE and their 
proved efficiency, $\mathrm{Pt} / \mathrm{rGO}$ and bimetallic $\mathrm{AuPt} / \mathrm{rGO}$ anodes are expected to be largely used in alkaline glucose fuel cells.

To obtain enough products to analyze, the fuel cell was maintained in nearly optimized conditions during a long time; the current density was set to correspond to the value just before the highest power density, $1 \mathrm{~mA} \mathrm{~cm}{ }^{-2}$ for $\mathrm{Au}_{70} \mathrm{Pt}_{30} / \mathrm{rGO}$ anode and $1.5 \mathrm{~mA} \mathrm{~cm}{ }^{-2}$ for $\mathrm{Au} / \mathrm{rGO}$ and $\mathrm{Pt} / \mathrm{rGO}$ anodes. As can be seen in Figure 10, the cell voltage decreases as function of time because of the glucose consumption at the anode.

At the end of the testing, the anodic solution was extracted off the cell, neutralized on cation exchange resin and lyophilized for $24 \mathrm{~h}$. The resulting solid was diluted in water and injected in ionic liquid chromatography equipped with a conductimetric detector to reveal the produced carboxylate species. These products were determined by comparing the retention times to standard analytes under similar elution conditions (Figure 11). Accordingly, gluconate $(8.4 \mathrm{mM})$ and glucuronate $(0.2 \mathrm{mM})$ were detected as the sole glucose oxidation products i.e without detectable compounds issued from C-C bond cleavage. If gluconate is already known to be the main glucose oxidation product in alkaline media when noble metal catalysts are employed [49], the presence of glucuronate which results from the oxidation of the primary alcohol at C6-position, reveals importantly that the electrocatalysts synthesized from BAE are selective [50].

\section{Conclusion}

In this paper, we demonstrated the excellent reactivity of glucose in alkaline fuel cell over catalysts made of $\mathrm{Au}$ and $\mathrm{Pt}$ nanoparticles deposited onto reduced graphene oxide (rGO). The BAE synthesis allowed to lead to small-sized and well-dispersed nanoparticles able to catalyze glucose oxidation in alkaline fuel cell with higher electrochemical performance. As result, these fuel cell delivered a power density of $1080 \mu \mathrm{W} \mathrm{cm}$ ch $^{-2}$ with glucose concentration 5 times lower 
than these in recent literature. This improvement of electrocatalytic performances can be attributed to the strong interaction between the metal nanoparticles and the $\mathrm{sp}^{2}$ carbon substrate, and the excellent electrical properties of rGO. By analysis of oxidation products from glucose $/ \mathrm{O}_{2}$ fuel cell we have demonstrated that gluconate and glucuronate were selectively produce without any detectable chemical issued from the C-C bond cleavage. This point is of great importance for implantable devices in order to preclude toxic product release in living body.

\section{Acknowledgments}

Authors acknowledge the financial support from the IMABIC project funded by the French

National Research Agency (ANR), the European Union (ERDF) and "Région NouvelleAquitaine". 


\section{References}

1. A. T. Yahiro, S. M. Lee, D. O. Kimble, Biochim. Biophys. Acta 88, 375-383 (1964)

2. R. M. Allen, H. P. Bennetto, Appl Biochem Biotechnol 39, 27-40 (1993)

3. E. Katz, I. Willner, A. B. Kotlyar, J. Electroanal. Chem. 479, 64-68 (1999)

4. D. H. Park, J. G. Zeikus, Biotechnol Bioeng 81, 348-355 (2003)

5. A. Heller, Phys. Chem. Chem. Phys. 6, 209-216 (2004)

6. C. H. A. Tsang, D. Y. C. Leung, Solid State Sci 71, 123-129 (2017)

7. P. Song, L. L. He, A. J. Wang, L. P. Mei, S. X. Zhong, J. R. Chen, J. J. Feng, J. Mater. Chem. A 3, 5321-5327 (2015)

8. F. Largeaud, K. B. Kokoh, B. Beden, C. Lamy, J. Electroanal. Chem. 397, 261-269 (1995)

9. L. A. Larew, D. C. Johnson, J. Electroanal. Chem. 262, 167-182 (1989)

10. Y. B. Vassilyev, O. A. Khazova, N. N. Nikolaeva, J. Electroanal. Chem. 196, 105-125 $(1985)$

11. B. Beden, F. Largeaud, K. B. Kokoh, C. Lamy, Electrochim. Acta 41, 701-709 (1996)

12. A. Habrioux, E. Sibert, K. Servat, W. Vogel, K. B. Kokoh, N. Alonso-Vante, J. Phys. Chem. B 111, 10329-10333 (2007)

13. S. J. Yao, A. J. Appleby, A. Geisel, H. R. Cash, S. K. Wolfson, Nature 224, 921-922 (1969)

14. D. Basu, S. Sood, S. Basu, Chem Eng J 228, 867-870 (2013)

15. D. Basu, S. Basu, Int. J. Hydrogen Energy 36, 14923-14929 (2011)

16. B. Seger, P. V. Kamat, J. Phys. Chem. C 113, 7990-7995 (2009)

17. J. J. Wang, G. P. Yin, Y. Y. Shao, S. Zhang, Z. B. Wang, Y. Z. Gao, J. Power Sources 171, $331-339(2007)$

18. C. Lafforgue, M. Chatenet, L. Dubau, D. R. Dekel, ACS Catal. 8, 1278-1286 (2018)

19. A. Zadick, L. Dubau, N. Sergent, G. Berthomé, M. Chatenet, ACS Catal. 5, 4819-4824 (2015) 
20. Z. Li, Z. An, Y. Guo, K. Zhang, X. Chen, D. Zhang, Z. Xue, X. Zhou, X. Lu, Talanta 161, $713-720(2016)$

21. J. W. Ma, A. Habrioux, Y. Luo, G. Ramos-Sanchez, L. Calvillo, G. Granozzi, P. B. Balbuena, N. Alonso-Vante, J. Mater. Chem. A 3, 11891-11904 (2015)

22. S. Navalon, A. Dhakshinamoorthy, M. Alvaro, H. Garcia, Coord. Chem. Rev. 312, 99-148 (2016)

23. S. Zoladek, I. A. Rutkowska, M. Blicharska, K. Miecznikowski, W. Ozimek, J. Orlowska, E. Negro, V. Di Noto, P. J. Kulesza, Electrochim. Acta 233, 113-122 (2017)

24. Q. Tang, Z. Zhou, Z. F. Chen, Nanoscale 5, 4541-4583 (2013)

25. S. Ghosh, H. Remita, P. Kar, S. Choudhury, S. Sardar, P. Beaunier, P. S. Roy, S. K. Bhattacharya, S. K. Pal, J. Mater. Chem. A 3, 9517-9527 (2015)

26. J. W. Ma, A. Habrioux, C. Morais, A. Lewera, W. Vogel, Y. Verde-Gomez, G. RamosSanchez, P. B. Balbuena, N. Alonso-Vante, ACS Catal. 3, 1940-1950 (2013)

27. C. Wang, D. Astruc, Prog. Mater Sci. 94, 306-383 (2018)

28. P. Tonda-Mikiela, T. W. Napporn, C. Morais, K. Servat, A. Chen, K. B. Kokoh, J. Electrochem. Soc. 159, H828-H833 (2012)

29. Y. Holade, A. Lehoux, H. Remita, K. B. Kokoh, T. W. Napporn, J. Phys. Chem. C 119, $27529-27539(2015)$

30. Y. Holade, C. Morais, S. Arrii-Clacens, K. Servat, T. W. Napporn, K. B. Kokoh, Electrocatalysis 4, 167-178 (2013)

31. R. Aljishi, G. Dresselhaus, Phys Rev B 26, 4514-4522 (1982)

32. R. E. Shroder, R. J. Nemanich, J. T. Glass, Phys Rev B 41, 3738-3745 (1990)

33. M. Veres, S. Toth, A. Koos, Diam Relat Mater 17, 1692-1696 (2008)

34. M. A. Pimenta, G. Dresselhaus, M. S. Dresselhaus, L. G. Cancado, A. Jorio, R. Saito, Phys. Chem. Chem. Phys. 9, 1276-1290 (2007) 
35. L. C. Nistor, J. Vanlanduyt, V. G. Ralchenko, T. V. Kononenko, E. D. Obraztsova, V. E. Strelnitsky, Appl. Phys. A. 58, 137-144 (1994)

36. T. Jawhari, A. Roig, J. Casado, Carbon 33, 1561-1565 (1995)

37. J. H. Lehman, M. Terrones, E. Mansfield, K. E. Hurst, V. Meunier, Carbon 49, 2581-2602 (2011)

38. L. G. Cancado, K. Takai, T. Enoki, M. Endo, Y. A. Kim, H. Mizusaki, A. Jorio, L. N. Coelho, R. Magalhaes-Paniago, M. A. Pimenta, Appl. Phys. Lett 88, 163106 (2006)

39. I. Abidat, C. Morais, S. Pronier, N. Guignard, J. D. Comparot, C. Canaff, T. W. Napporn, A. Habrioux, A. S. Mamede, J. F. Lamonier, K. B. Kokoh, Carbon 111, 849-858 (2017)

40. M. O. Pedersen, S. Helveg, A. Ruban, I. Stensgaard, E. Laegsgaard, J. K. Norskov, F. Besenbacher, Surf. Sci 426, 395-409 (1999)

41. Y. Holade, K. Servat, T. W. Napporn, K. B. Kokoh, Electrochim. Acta 162, 205-214 (2015) 42. A. Habrioux, D. Diabaté, J. Rousseau, T. Napporn, K. Servat, L. Guétaz, A. Trokourey, K. Kokoh, Electrocatalysis 1, 51-59 (2010)

43. S. Hebie, T. W. Napporn, C. Morais, K. B. Kokoh, Chemphyschem 17, 1454-1462 (2016) 44. Y. Holade, N. Sahin, K. Servat, T. Napporn, K. Kokoh, Catalysts 5, 310-348 (2015)

45. L. Li, K. Scott, E. H. Yu, J. Power Sources 221, 1-5 (2013)

46. K. Elouarzaki, M. Holzinger, A. Le Goff, J. Thery, R. S. Marks, S. Cosnier, J. Mater. Chem A 4, 10635-10640 (2016)

47. G. Siva, M. A. Aziz, G. G. Kumar, ACS Sustain. Chem. Eng. 6, 5929-5939 (2018)

48. Y. Zhao, X. H. Liu, X. Wang, P. P. Zhang, J. F. Shi, Int. J. Hydrogen Energy 42, 29863$29873(2017)$

49. Y. Holade, K. Servat, T. W. Napporn, C. Morais, J. M. Berjeaud, K. B. Kokoh, ChemSusChem 9, 252-263 (2016) 
50. R. Wojcieszak, I. M. Cuccovia, M. A. Silva, L. M. Rossi, J. Mol. Catal. A: Chem. 422, 35$42(2016)$ 


\section{Figures Caption}

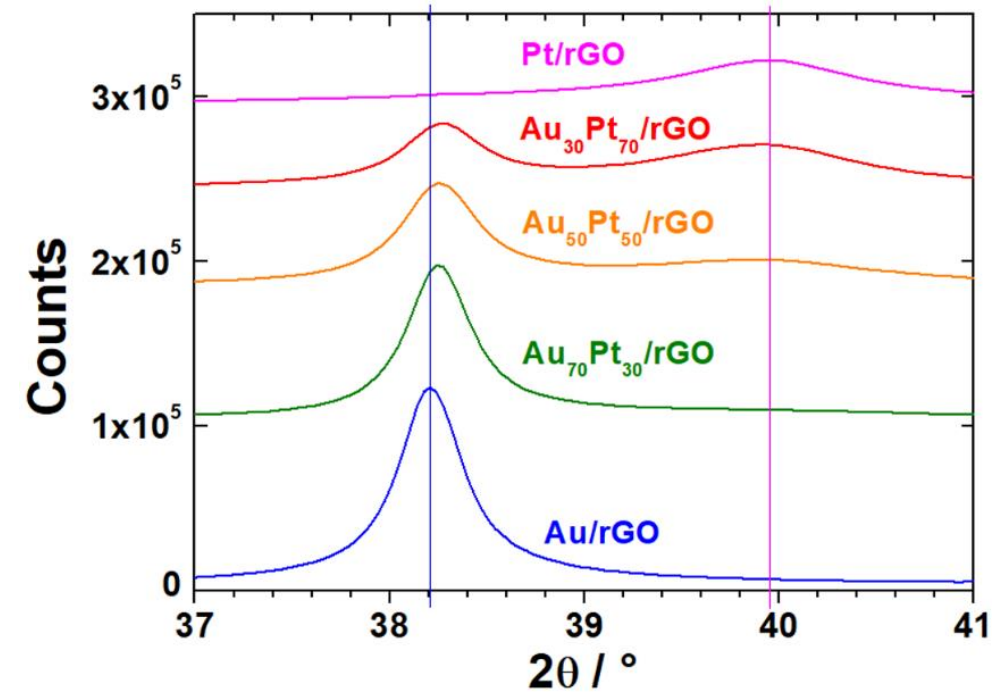

Figure 1: XRD patterns in the window $2 \theta=37$ to $41^{\circ}$ of rGO supported catalysts.

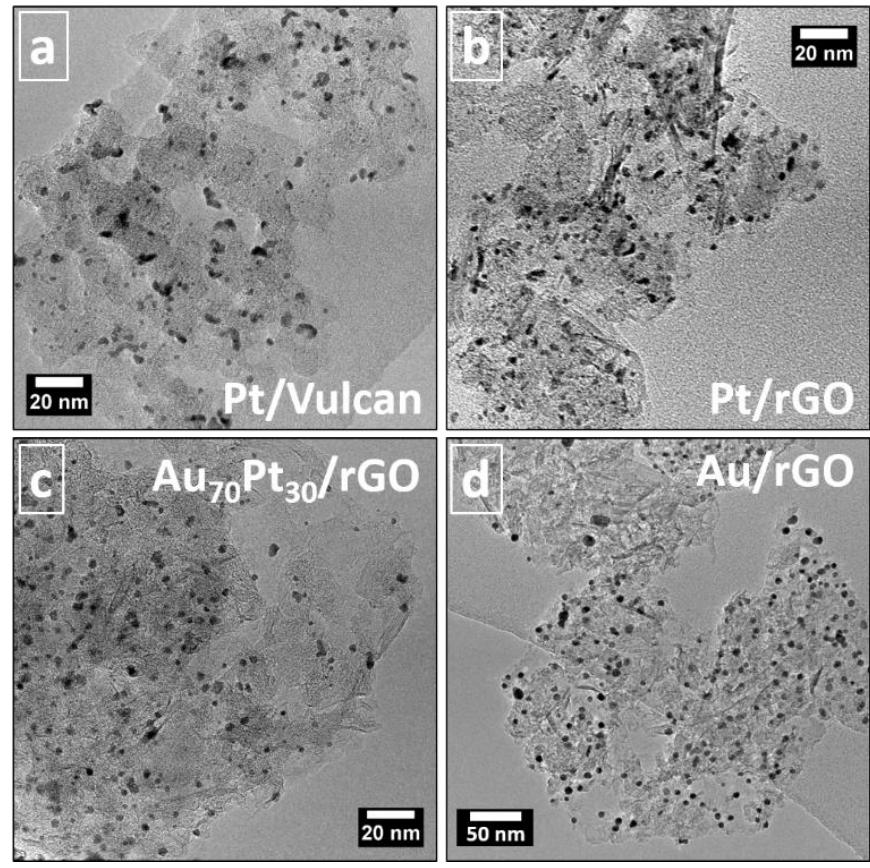

Figure 2: TEM images of (a) Pt/Vulcan, (b) $\mathrm{Pt} / \mathrm{rGO}$, (c) $\mathrm{Au}_{70} \mathrm{Pt}_{30} / \mathrm{rGO}$ and (d) $\mathrm{Au} / \mathrm{rGO}$. 

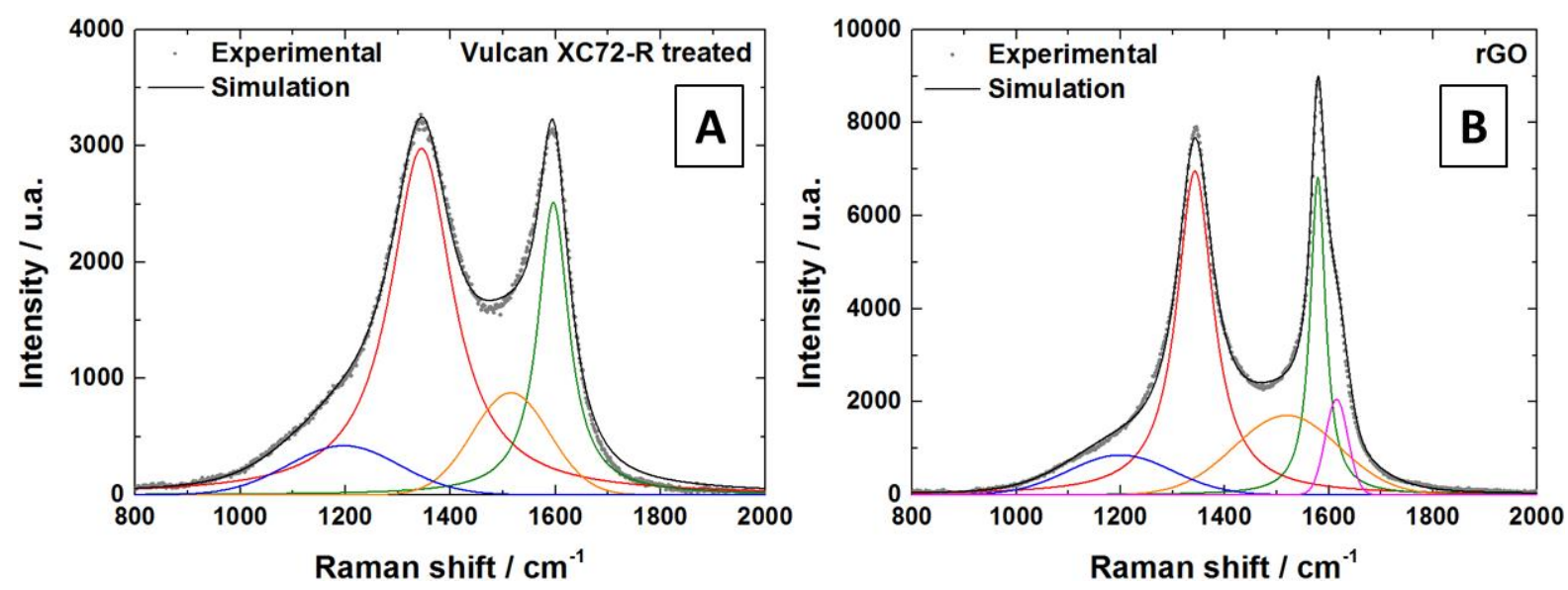

Figure 3: Deconvoluted Raman spectra of (a) Vulcan support and (b) rGO support.
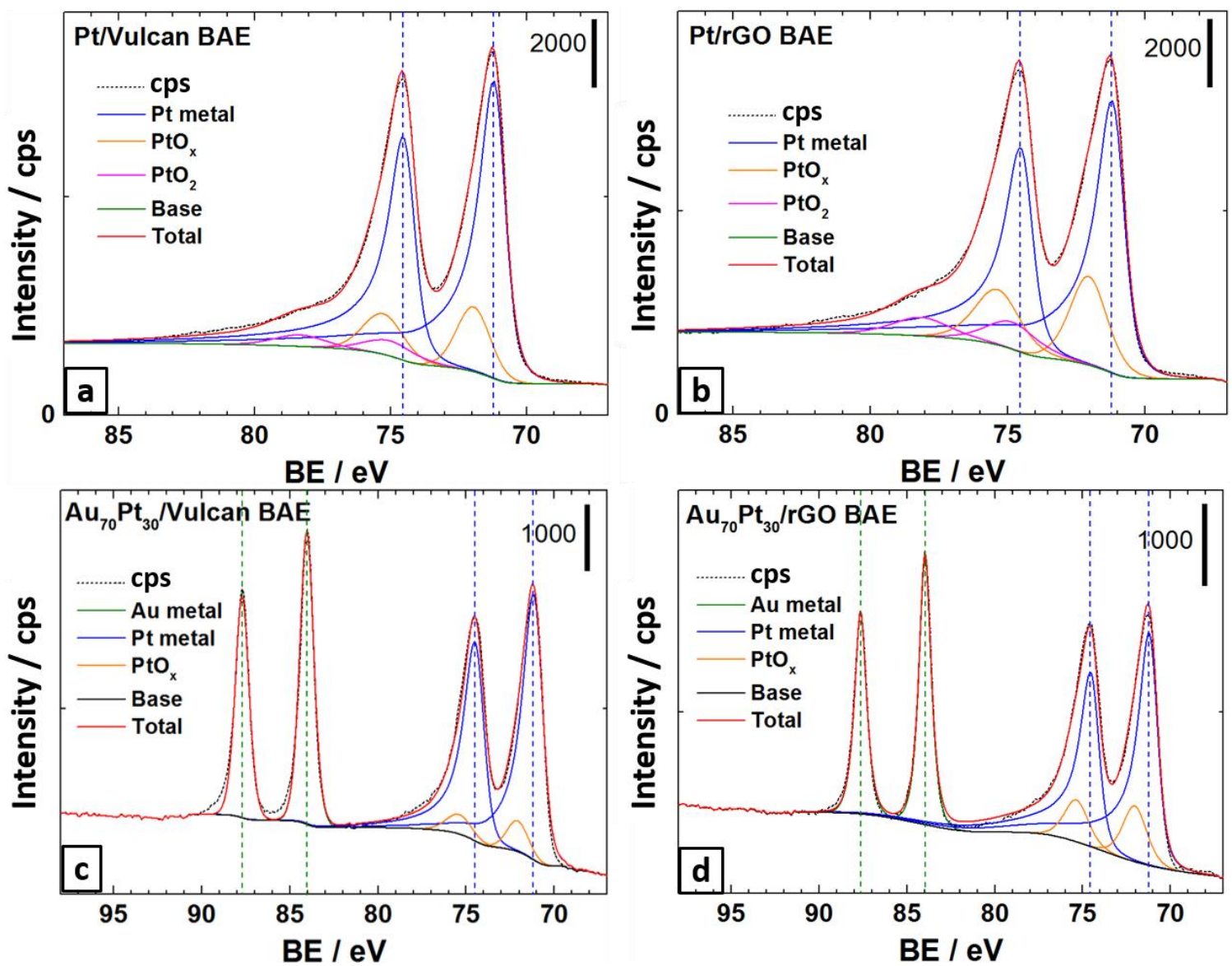

Figure 4: XPS spectra of (a) Pt/Vulcan, (b) Pt/rGO, (c) $\mathrm{Au}_{70} \mathrm{Pt}_{30} / \mathrm{Vulcan}$ and (d) $\mathrm{Au}_{70} \mathrm{Pt}_{30} / \mathrm{rGO}$. 


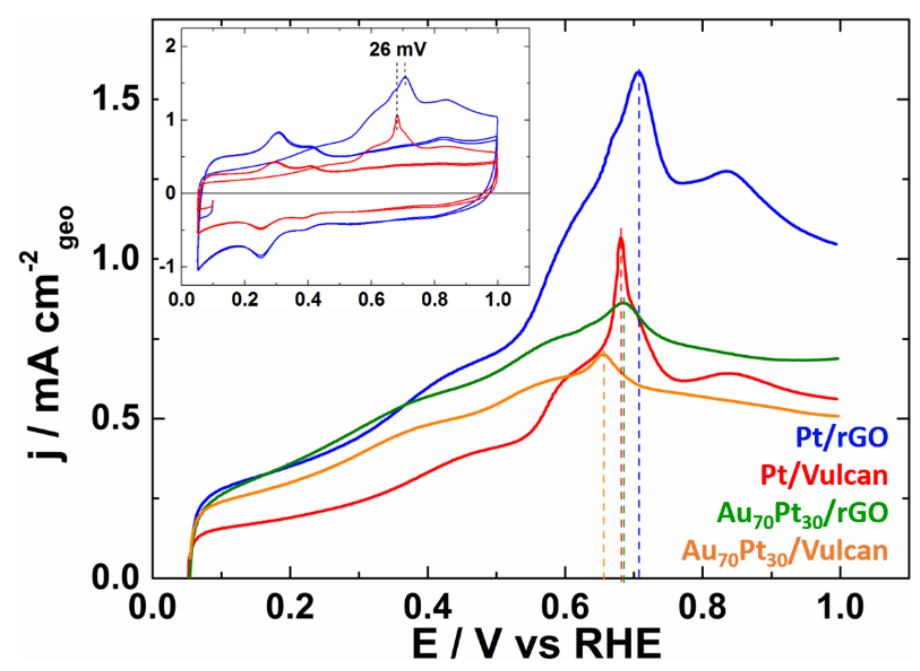

Figure 5: First cycle anodic scans of CO-stripping recorded at $20 \mathrm{mV} \mathrm{s}^{-1}$ in $0.1 \mathrm{M} \mathrm{KOH}$, after $\mathrm{CO}$ adsorption by polarization at $0.10 \mathrm{~V}$ vs RHE. Inset: cyclic voltammograms of CO-stripping for Pt at the surface of the two carbon substrates (rGO and Vulcan).
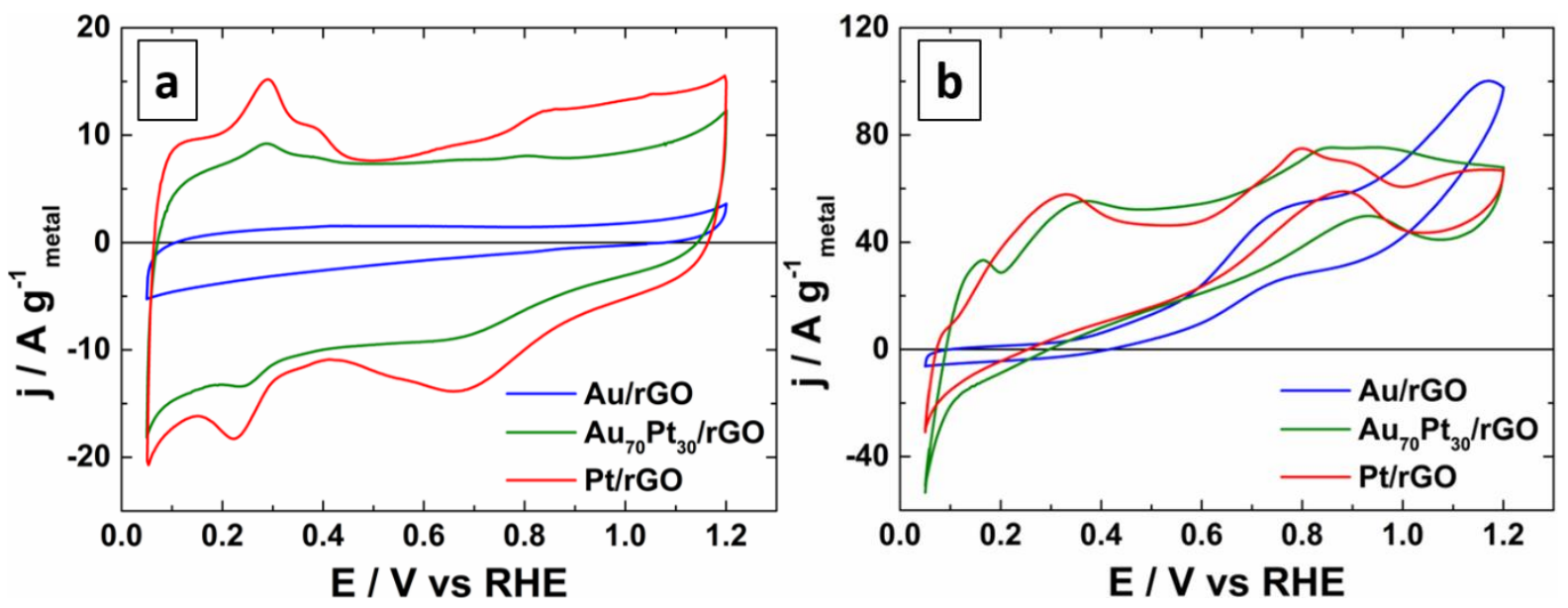

Figure 6: Cyclic voltammograms recorded at $20 \mathrm{mV} \mathrm{s}^{-1}$ in $0.1 \mathrm{M} \mathrm{KOH} \mathrm{(a)} \mathrm{in} \mathrm{the} \mathrm{absence} \mathrm{and}$ (b) in the presence of $50 \mathrm{mM}$ glucose at room temperature of $\mathrm{Au} / \mathrm{rGO}, \mathrm{Au}_{70} \mathrm{Pt}_{30} / \mathrm{rGO}$ and $\mathrm{Pt} / \mathrm{rGO}$. 


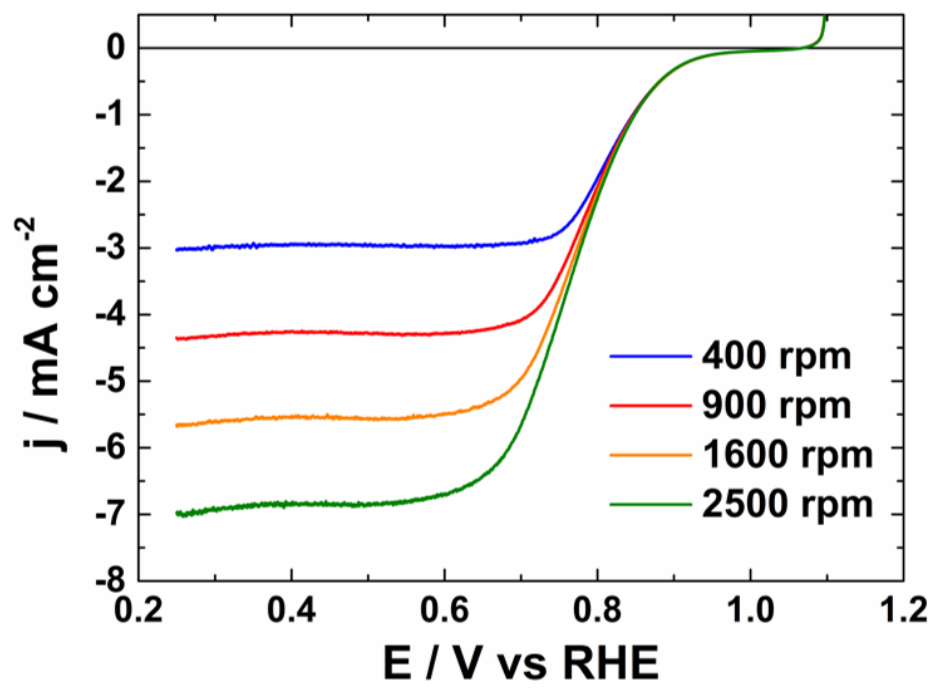

Figure 7: ORR polarization curves recorded on a Pt/Vulcan catalyst at $5 \mathrm{mV} \mathrm{s}^{-1}$ with a rotating disk electrode working at various rotation rates in $\mathrm{O}_{2}$-saturated $0.1 \mathrm{M} \mathrm{KOH}$.

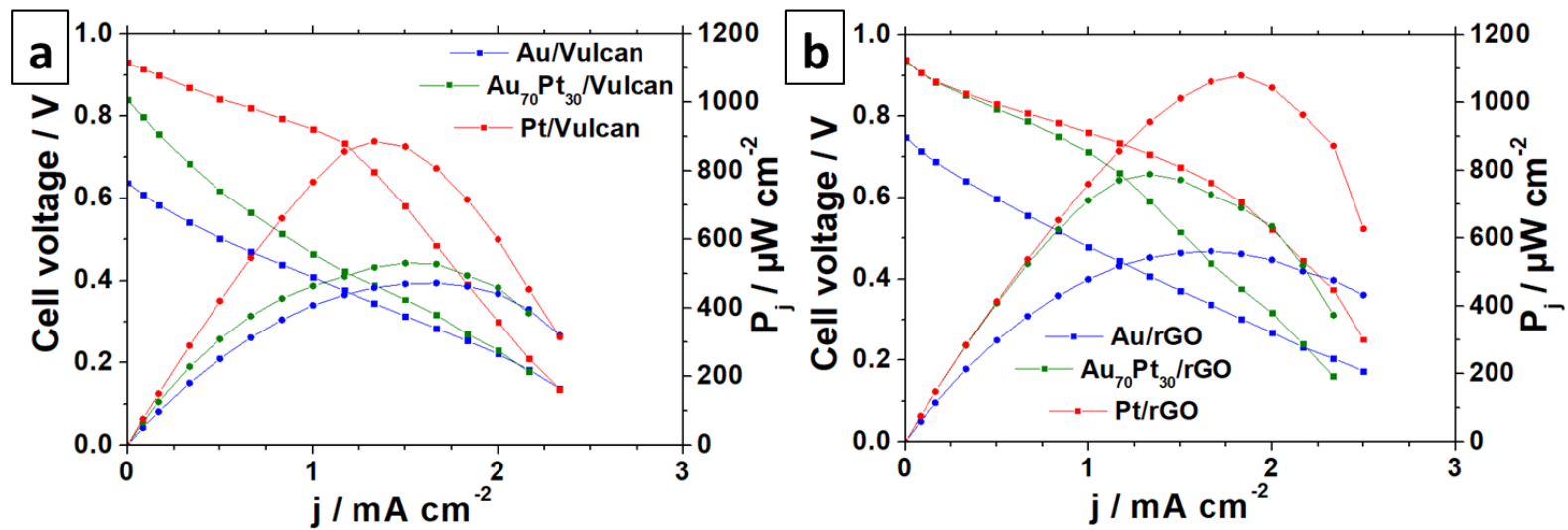

Figure 8: Polarization and power density curves of (a) Vulcan and (b) rGO supported catalysts as anodes and $\mathrm{Pt} / \mathrm{Vulcan}$ as cathode in $0.1 \mathrm{M} \mathrm{KOH}$. The concentration of glucose in the anodic compartment is $50 \mathrm{mM}$, and $\mathrm{O}_{2}$ is bubbled in the cathodic compartment. Electrode surface: 0.6 $\mathrm{cm}^{2}$; Metal loading: $0,19 \mathrm{mg}_{\text {metal }} \mathrm{cm}^{-2}$. 


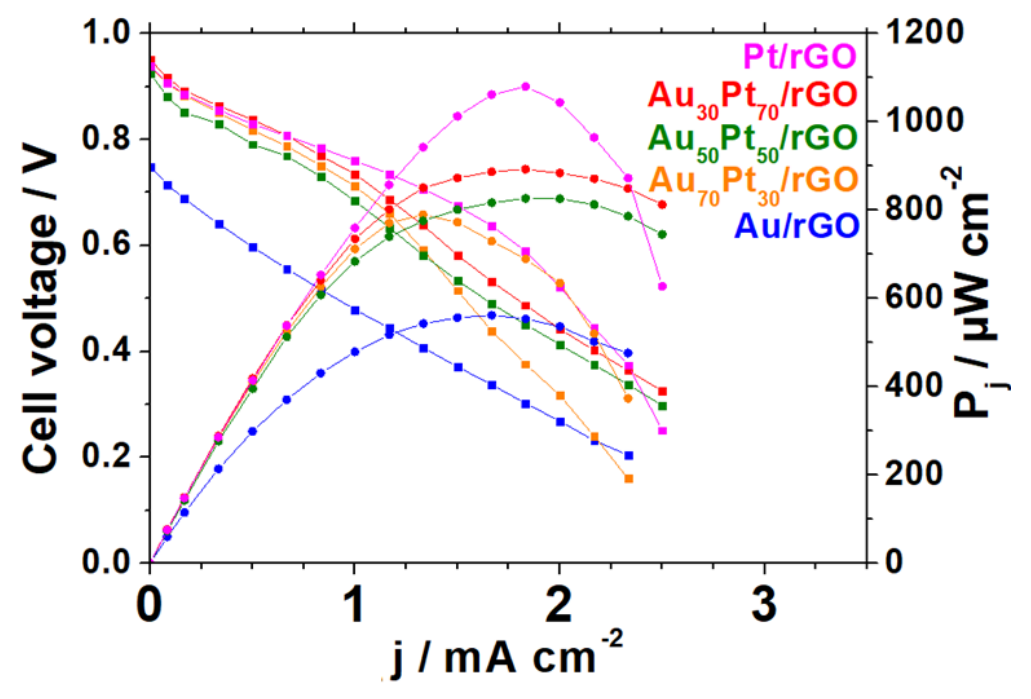

Figure 9: Polarization and power density curves of rGO supported catalysts as anodes and $\mathrm{Pt} / \mathrm{Vulcan}$ as cathode in $0.1 \mathrm{M} \mathrm{KOH}$. The concentration of glucose in the anodic compartment is $50 \mathrm{mM}$, and $\mathrm{O}_{2}$ is bubbled in the cathodic compartment. Electrode surface: $0.6 \mathrm{~cm}^{2}$; Metal loading: $0.19 \mathrm{mg}_{\text {metal }} \mathrm{cm}^{-2}$.

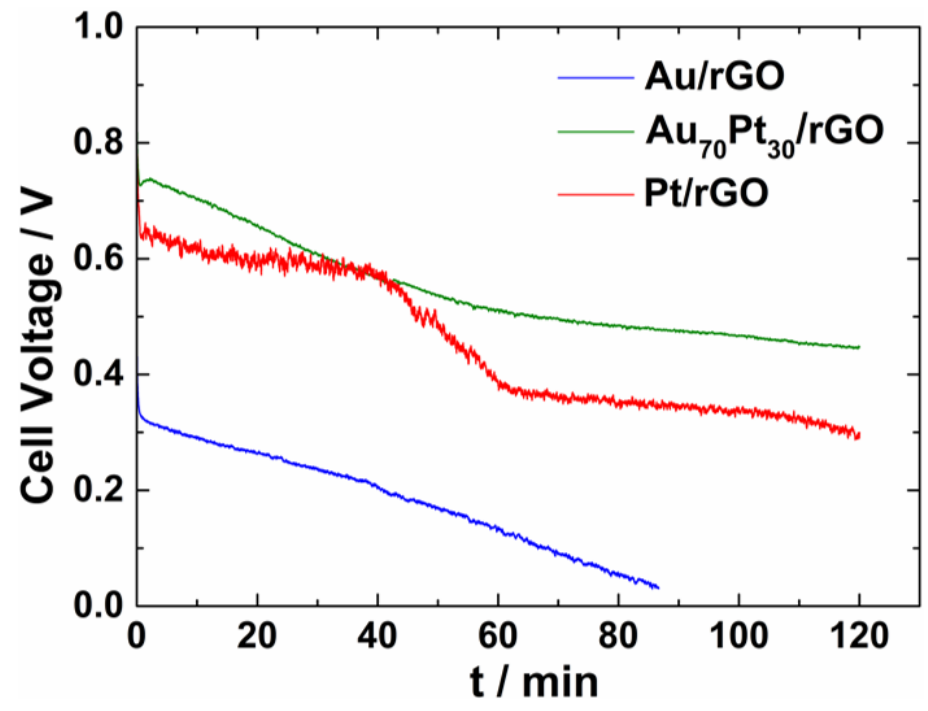

Figure 10: Evolution of GFC voltage at $1.5 \mathrm{~mA} \mathrm{~cm}^{-2}$ with $\mathrm{Au} / \mathrm{rGO}$ and $\mathrm{Pt} / \mathrm{rGO}$ as anodes and $\mathrm{Pt} /$ Vulcan as cathode, and at $1 \mathrm{~mA} \mathrm{~cm}^{-2}$ with $\mathrm{Au}_{70} \mathrm{Pt}_{30} / \mathrm{rGO}$ as anode and same cathode, in 0.1 $\mathrm{M} \mathrm{KOH}+50 \mathrm{mM}$ glucose in anodic compartment and $\mathrm{O}_{2}$ bubbling in cathodic compartment. 


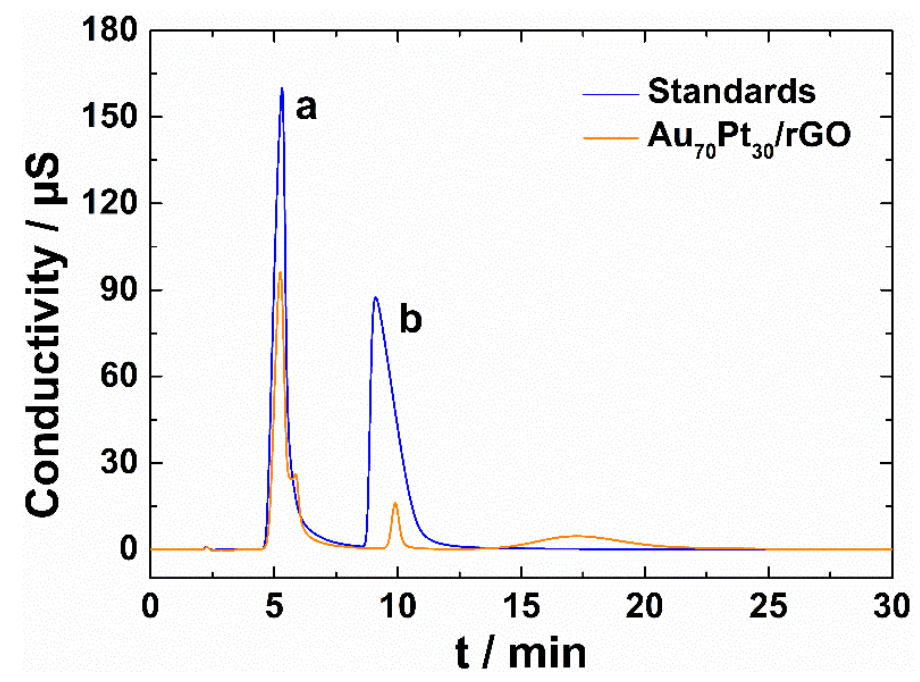

Figure 11: Ionic chromatograms of standards samples (a) gluconate $10 \mathrm{mM}$ and (b) glucuronate $5 \mathrm{mM}$; and of $50 \mathrm{mM}$ glucose alkaline solution oxidized in the fuel cell with $\mathrm{Au}_{70} \mathrm{Pt}_{30} / \mathrm{rGO}$ for 2 hours at $1 \mathrm{~mA} \mathrm{~cm}^{-2}$. 
Table 1: Graphitization degree and size of the graphitic domains of Vulcan and rGO extracted from Raman spectra.

\begin{tabular}{lll}
\hline & Vulcan XC 72 R treated & rGO \\
\hline $\mathbf{I}_{\mathbf{D}} / \mathbf{I}_{\mathbf{G}}$ & 2.26 & 2.31 \\
\hline $\mathbf{L a} / \mathbf{n m}$ & 8.5 & 8.3 \\
\hline
\end{tabular}

Table 2: Calculated SECSA of the prepared electrode materials from CO-stripping measurements.

\begin{tabular}{lllll}
\hline Catalyst & Pt/Vulcan & Pt/rGO & Au70Pt30/Vulcan & Au70Pt30/rGO \\
\hline SECSA $/ \mathbf{~ m}^{\mathbf{2}} \mathbf{g}^{-1} \mathbf{P t}$ & 26 & 51 & 96 & 129 \\
\hline
\end{tabular}

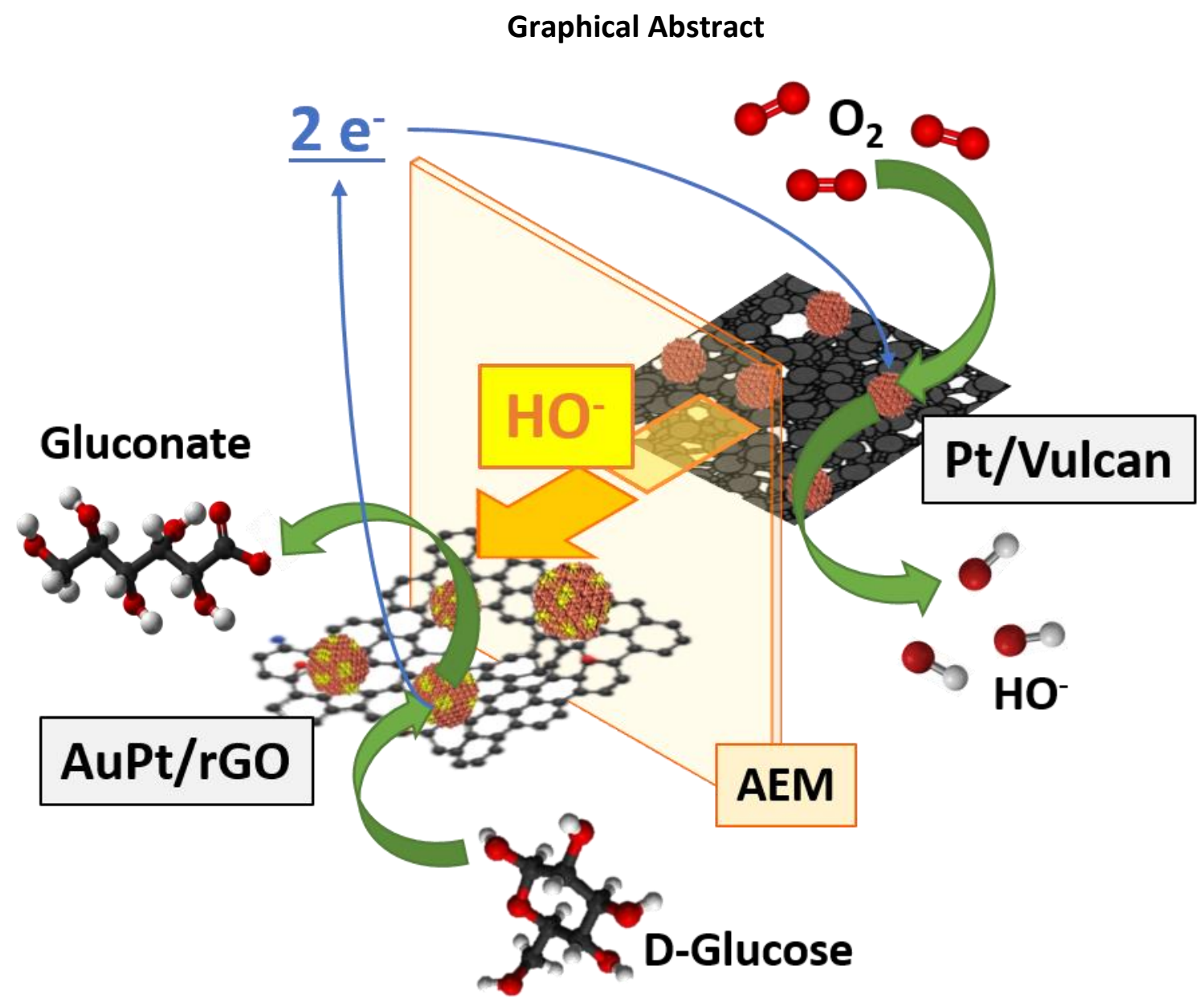

